This article has been scanned by iThenticat No plagiarism detected

Volume 3, Issue 5, October 2021

p. 334-346

\title{
HAPPINESS A QURANIC PERSPECTIVE
}

\author{
http://dx.doi.org/10.47832/2757-5403.5-3.29
}

\section{Doaa Abdulkareem ABDULLAH 1 \& Nesaif Jassim Mohammed AL-KHAFAJI²}

\begin{abstract}
:
In this study, we will study the concept of happiness, a view of happiness from the point of view of famous psychologists and philosophers, and combining Islamic thought with philosophy. This study is a basic research the different debates on the concept of happiness in the Quran. And we discuss in this article tools of happiness in life. Happiness in the hereafter, or everlasting felicity, is the ultimate goal of the believer. Although happiness is a very relative concept, it is generally the feeling that occurs when people are satisfied with the material and spiritual states, they are in. The greatest blessing bestowed upon mankind is within us and within our reach. A wise person knows how to be happy with what he has no matter what, rather than wishing what he does not have. It is a state of coinciding with what happens and what they want. All normal people desire happiness and want their happiness to be permanent. Anyone who sees that this world cannot satisfy their desire for happiness understands that this desire cannot be satisfied without God. Sometimes even love and compassion can make one feel happy. The research dealt with the names of the happiness in the Quran with their semantic aspects, then we restricted these names, and these were placed alphabetically in the letters that indicate how many times they appeared in the Quran. Later it was divided into semantic groups and analyzed within these groups, this analysis focuses on the presentation of the lexical concept and semantic content for each. In fact, the subject was also discussed within the rational framework. happiness does have a pretty important role in our lives, and it can have a huge impact on the way we live our lives. The first part of the present study focuses on how ethics philosophers explain an interpret happiness and whether it is possible to reach real happiness. In the second part, the virtues that ethics philosophers view
\end{abstract}

\footnotetext{
${ }^{1}$ Researcher, Federation of Arab Trainers Syndicates, Baghdad, Iraq, yellow.rose.seviyorum@gmail.com, https://orcid.org/0000-0001-8506-7164

${ }^{2}$ Prof.Dr. , Diyala University, Iraq, Dr.Nessayif@coehuman.uodiyala.edu.iq, https://orcid.org/0000-0002-9746$\underline{8499}$
}

Copyright (C) Published by IJHER Journal, www.ijherjournal.com Rimar Academy, Fatih, Istanbul, 34093 Turkey

All rights reserved 
as the fundamental elements in attaining happiness. Also, this section examines the definition of virtue, virtue types, sub-virtues, and the characteristics of virtuous acts. Consequently, this study disclosed that ancient and medieaval philosophers regarded the pursuit of happiness as a fundamental goal in one"s life, and that these philosophers agreed that this goal could be accomplished by leading a virtuous life .

Key words: Quran, Translation of The Qur'an, Sura index, Happiness, Platon, ibn Sina, Al-Farabi.

\title{
KUR'ÂN-I KERÎM PERSPEKTİFİNDEN MUTLULUĞUN
}

\author{
Doaa Abdulkareem ABDULLAH \\ Nesaif Jassim Mohammed AL-KHAFAJI
}

\section{Öz}

Biz bu çalışmade mutluluk kavramını, Filozoflar ve psikologlar bir bakış açısından mutluluk kavramının gerçek anlamı ve İslâm düşüncesini felsefe ile buluşturup harmanlayan mutluluk anlayışını inceleyeceğiz. Bu çalışma Kuran Kerîm'de mutluluğun kavramı üzerine yapılan farklı tartışmaların temel bir araştırmasıdır. Ve bu araştırmad hayatta mutluluk araçlarını tartışıoruz. Ahirette mutluluk ya da sonsuz mutluluk, müminin son amacidır. Mutluluk çok göreceli bir kavram olmasına rağmen genel olarak insanın içinde bulunmuş olduğu maddi ve manevi hallerden razı olduğunda meydana gelen duygudur. İnsanoğluna bahşedilmiş en büyük nimet, içimizde ve ulaşabileceğimiz yerdedir. Bilge bir kişi sahip olmadığını arzulamak yerine, her ne olursa olsun kendinde olanla mutlu olmay1 bilir. Gerçekleşen şeylerin istediği şeylerle örtüşme durumudur. Bütün normal insanlar mutluluğu arzular ve mutluluklarının sürekli olmasını ister...Bu dünyanın, mutluluk arzusunu tatmin edemediğini gören herkes, bu arzunun Allah olmadan tatmin olamayacağını anlar. Bazen insan için sadece sevgi ve şefkat dahi kendini mutlu hissetmesini sağlayabilir. Araştırmada, Kuran Kerîm'deki mutluluk isimlerinin anlamsal yönleri ile ilgilendikten sonra bu isimleri topladık ve bunlar, Kuran Kerîm'da kaç kez göründüklerini gösteren harflerine alfabetik olarak yerleştirildi. Daha sonra anlamsal gruplara ayrılmış ve bu gruplar içinde analiz edilmiş, bu analiz her biri için sözcüksel kavram ve anlamsal içeriğin sunumuna odaklanmaktadır. Aslında, aklî çerçevede de ele alınmıstır. mutluluğun hayatlarımızda oldukça önemli bir rolü vardır, hayatımızı yaşama şeklimiz üzerinde çok büyük bir etkisi olabilir. Çalışmanın ilk bölümünde mutluluğun ahlâk filozofları tarafından nasıl yorumlandığı, gerçek mutluluğa ulaşılıp ulaşılamayacağı gibi temel soruların cevapları arandı. İkinci bölümde ise ahlâk filozoflarının mutluluğa ulaşmanın temel unsuru olarak gördüğü erdemlere yer verildi. Bu bölümde erdemin tarifi, erdem çeşitleri, temel erdemlerin alt türleri, erdemli davranışın özellikleri gibi konular karşılaştırmalı olarak incelendi. Bu değerlendirmeler neticesinde teleolojik ahlâk anlayışına sahip ilk ve orta çağ filozoflarının mutluluğu temel bir gaye olarak gördükleri, bu gayeye 
ulaşmanın da ancak erdemli bir hayat sürmekle mümkün olduğu konusunda hemfikir oldukları sonucuna ulaşıldı.

Anahtar Kelimeleri: Kuran Kerîm, Meâl, Sure, Mutluluk, Platon, İbn Sînâ, Farabî.

\section{Giriş}

Arapçada saadet olarak tanımlanan kelimenin İngilizce karşılığı olarak "happiness" kavramı kullanılır. "Happiness" zengin olma talihi anlamına gelir. Türkçede ise, mutluluk sözcüğü bütün isteklerin yerine getirilmesi anlamında kullanılır. "Mesut olma" kavramı mutluluk ile eş anlamlıdır. (Acaboğa, 2007) Saadet'in ne anlama geldiğini anlamak için, evvela bu terimin tam karşıtı olan şekavetin kısa bir açıklaması zorunlu görünüyor. İlk dönemlerden bu tarafa Arapça lügatler ve Kur'an, şekavet terimini, İngilizcedeki tam karş1lı̆̆ ile, 'büyük talihsizlik', 'sefalet', 'ümitsizlik', 'zorluk', 'sstırap' gibi anlamlarda kullanmaktadır. Bunlara biçilen anlamın gerçekleşmesi, açıkçası, ciddi zahiri ve batıni faaliyeti gerektirmektedir. Aslında şekavet bütün sefalet türlerini kapsayan bir cins isimdir, bu yüzden benzer şartları açıklayan ama kendi bağlamları içinde daha özel bir anlama sahip olan diğer terimler, şekavetin olussturucu unsurlarıdır. (DÜZGÜN, 2007)

"Mutluluk" kavramına gelindiğinde ise, net bir tasvir yapabilmenin güçlüğü burada da kendini gösterir. Mutluluk düşünce tarihinin en temel felsefe ve ahlak sorunlarından biri olduğu gibi, insanlığın da bıkıp usanmadan peşinden koşturduğu en büyük hedeflerinden olagelmisstir. O zaman mutluluk, kendi başına ele alınan bir kavram olmaktan uzak görünmektedir. Mutluluğun ilintili olduğu en önemli kavramın ahlak olduğu, hatta birçok tanımın ahlak üzerinden yapıldığı göz önüne alınırsa, ahlakın mutluluk üzerindeki önemi de ortaya çıkmış bulunmaktadır. (Yıldız, 1997)Mutluluk araştırması hisleri sadece ölçmez, ölçtüğü şeyi de yorumlar. Mutluluğu ölçmek öncelikle mutluluk dağılımı hakkında bilgi sağlar. Mutluluk araştırmaları mutluluğun nerede yer aldığını gösteren ve büyük oranda karşılaştırma modeline dayalı veri tabanları üretmiştir. Mutluluk veri tabanları bize hangi bireylerin, grupların, ulus-devletlerin diğerlerinden daha mutlu olduğunu gösteriyor. Mutluluk bilimi, mutluluk seviyeleri ile sosyal göstergeler arasında bağıntı kurarak "mutluluk göstergesi" denen şeyleri yaratır. Mutluluk göstergeleri bize ne tür insanların daha mutlu olduğunu söyler; hem mutluluk ölçütü hem mutluluk öngörücüsü işlevi görür.Frey ve Stutzer'in Happiness and Economics'te (Mutluluk ve İktisat) öne sürdükleri gibi, sosyal göstergeler "mutluluk psikogram" ları yaratarak farklı türde insanların ne kadar mutlu olacağını öngörebilir. (Mayadağ, 31.05.2016)

Mutluluk, zihinsel ve duygusal bir durumdur. Hayata nasıl ve hangi perspektiften bakıldığ1, bardağın boş mu yoksa dolu tarafının mı görüldüğü, mutlu olma hissi için çok önemlidir. Mutluluk veya mutsuzluk hissi; insanın içinde bulunduğu durum ve koşulları nasıl algıladığı, yaşadığı küçük veya büyük deneyimleri iç dünyasına nasıl aktarmayı tercih ettiğiyle ilgili bir zihinsel ve duygusal süreçtir. Mutluluk veya mutsuzluk, aslında kişinin kendi tercihidir ve insan tarafından hem hissedilen duyumsanan hem de düşünülebilen zihinsel bir süreçtir. A. Winet, 'Blaise Pascal Üzerine İncelemeler'inde, insan doğasını durmaksızın tedirgin eden ruh ve akıl için mutluluğun, sadece en evrensellikle duyulan ve en sık olarak görülüp geçirilen değil de en güçlü olanı olduğunu savunur. Mutluluğun salt duyusal değil de aynı zamanda anlıkçı (intellectual) olduğunu ve yalnızca ruh için değil, akıl için de bir gereksinme olarak, gerçeğin bir bölümünü oluşturduğunu ifade eder. (Derinsu, 1986)

\section{Metin Ve Değerlendirme}

Çalışma, aşağda belirtilen üç ana başlık altında ele alınacatır.

1. Filozoflar ve psikologlar bir bakış açısından mutluluk kavramının gerçek anlamı. 
2. İslam'da mutluluğun anlamı.

3. Kur'an-1 Kerim'de mutluluk ilgili ayetleri.

\subsection{Filozoflar Ve Psikologlar Bir Bakış Açısından Mutluluk Kavramının Gerçek Anlamı}

Mutluluk, kadim zamanlardan itibaren asırlarca süregelen, insanın varoluşsal değeri ve aynı denklemde yer almıştır. İlginç olan şudur ki; bu alg1 nasıl bir dönüşüm geçirmiş, kendini gerçekleştiren insan modelinden, kullanışlı insan modeline nasıl geçiş yapıldığı yeterince izah edilememisstir. Bu noktada Martin Seligman'a hak vermek gerekir. Nitekim ona göre tramvatik savaşlar atlatan dünya insanı, yorgunluğuna rağmen yeniden var olma çabası içinde yaralarını sarmak zorunda kalmıştır. İnsanlık, filmin başa sarılmasıyla beraber tüm imkânlarını hasarın olduğu yere yoğunlaştırmıştır. İnsan ve ruhsal hastalıkları üzerine araştırma yapan bilim sahaları, insan yaralarına, acılarına, davranış bozukluklarına odaklanarak kadim birikimin insan tanımındaki eksenin bir miktar kaymasına neden olmuştur. (Akbaş, 2019)

Mutluluğun sırrı şudur: İlgilerinizi olabildiğince genişletin; sizi ilgilendiren şeylere karşı tepkilerinizin düşmanca değil, olabildiğince dostça olmasına bakın. Mutlu yaşam, büyük ölçüde, iyi ve dürüst yaşam demektir. Profesyonel ahlakçılar vazgeçmeye fazla yer vermişler, böyle yapmakla da önem damgasını yanlış yere vurmuşlardır. Bilinçli vazgeçme, kişiyi kendi içine kapanık yapar ve sürekli olarak yaptığı özveriyi düşünmesine yol açar; bunun sonucu olarak da; vazgeçmekle güdülen yakın ve uzak amaçlar gerçekleşmemiş olur. Gerekli olan, vazgeçme değil, ilgimizi dişa yönelterek, kendi erdeminden başka bir şey düşünmeyenlerin bilinçli olarak gösterebilecekleri davranışlan bizim hiç duraksamadan ve içten gelerek yapmamızdır. (Sağlamtürk, 2014)

Felsefe disiplininde mutluluk duygusunu meydana getiren üç basamaklı bir yapıdan bahsedilmektedir.Mutluluk duygusunun ilk basamağ1 insanda hazzın var olmas1 ayn1 zamanda acının olmaması durumuyla yaşanan genel iyilik hali olarak kabul edilmektedir.İkinci basamak, insan varlığının kendi çaba ve faaliyetleriyle kendini gerçekleştirme duygusunu elde etmesidir. Bu basamakta insanın hazların toplamından daha çok hazların uyumuna ve insanın bütün boyutlarıyla mutlu olabileceği ifade edilmektedir.Üçüncü basamakta, bireyin doğa yasalarına uyumlu, ölçülü ve özgürce yaşayabilmesidir.Kısaca bireyin yetkinlik halini kazanmasıdır. (CEVIZCI, 1997) Sokrates'te mutluluk, insan doğasının nihai gayesini olussturur. Mutluluğun kaynağı ve yegane mutluluk verici olan şey ise bilgidir. Mutluluğun önündeki en büyük engel de bilgisizliktir. Burada, Sokrates'in erdem konusundaki ünlü önermesini hatırlamakta fayda var: Erdem bilgidir, erdemsizlik de bilgisizliğe eşdeğerdir. Erdem olan bilgi aynı zamanda insanın özüne ilişkin bilgidir. Erdemi tanımlamanın bir yolu da onu kendini bilmeye eşitlemektir. O, bilgiyi ahlâkî eylemin dayanağı olarak araştırır. (Hünler, 2001)

Platon (M.Ö. 428-348) mutluluğa ulaştıracak yolun iyilik olduğunu düşünmektedir. Ona göre insan için en yüksek amaç iyi olmaktır. İnsanı iyi kılan doğruluk, ölçülülük ve adaletli olmaktır. Platon doğruluk, adalet ve ölçülülük gibi iyiliklerle mutluluğa ulaşılacağını bildirmektedir. Yaşadığı döneme imzasını atmış olan Platon, sadece bireysel mutluluğu konu olarak ele almamakta aynı zamanda toplumsal mutluluğa da dikkat çekmektedir. Toplumsal mutluluk için toplumsal ahlak ve devletin gerekliliğini savunmaktadır. (Akarsu, 1982) Aydınlanma döneminin filozoflarından Montaigne (1533-1592) mutluluğu erdeme bağlı olarak değerlendirmekte, erdemi ise aklın dışında olmayan bir yetkinlik olarak tarif etmektedir . (Eyupoğlu, 1997) Bazı düşünürler ise mutluluğa bir duygu olarak bakmaktadır. Schopenhauer gibi düşünürler mutluluğu tanımlarken, "mutluluğun, mutsuz olmama hali" olduğunu vurgular". Mutlu kişi, en çekici lezzetleri veya en güçlü zevkleri tatmış olan değil; hayatını gerek fiziksel gerek de ruhsal travmalar yaşamadan idame ettirendir. "Mutluluk bir duygudur. Duygularımız güdüler gibi davranışlarımızı harekete geçirir. Mutluluk yaptığımız iş sonunda hissettiğimiz duygudur ve adeta bizim ödülümüzdür”. (Öztekin, 2016) 
Epiktetos'a göre, insanlara rahatsızlı veren, olayların kendisi değil, bu olaylara getirdikleri bakış açısıdır. Bu bağlamda insan, hayatın anlamı veya anlamsızlığı konusunda kendi bakış açısını ve hayata baktığı yönü değiştirme potansiyeline sahiptir. Bakış açısı değişimi ile hayatın anlamsızlığından yakınan biri, kendine has bir anlam bulmakta zorlanmayacak ve bir anlam bulacaktır. Anlam deneyimi gibi, anlamsızlığın deneyimi de insanın bakış açısına bağlıdır. Burada anlamsızlık yaşayan insana sorulacak en önemli sorulardan biri; Hayatta ve dünyada hiçbir şeyin mi herhangi bir anlamı olmadığ 1 sorusudur. (Bora, 2014) Mutlu olma çabası, negatif ve pozitif olmak üzere iki yönlüdür. Bu bir yanda ac1 ve haz yoksunluğunun olmamasını, diğer yanda ise hazza ilişkin güçlü duyguların yaşanmasını amaçlamaktır. En dar anlamıyla, mutluluk zevk (haz) hissidir. Yaşamın amacinı belirleyen şey, haz ilkesinin düzenlenmesi ve zevk hislerini en üst düzeye çıkarma çabasıdır. (Sigmund Freud/Çev, 1989) Aristoteles,Nikomakhos'a Etik'in X.kitabında haz ve mutluluğun ayrımını detaylandırmıştır. Akıllı veya akıldan yoksun tüm canlılar acıdan kaçarak karşıt duygu durumu olan hazza yönelirler. Canlıların bu yönelimlerindeki ortaklık, hazzın mutluluk olabileceği teorisini güçlendiriyor gibi görünse de, Aristoteles mutluluğun hazda olmadığının temel dayanaklarına değinmektedir. Birbirini takip eden bu problem çokluğu için Aristoteles, felsefecinin gündemine aldığı meselelere yaklaşımına dair gereken ayrıntıyı dile getirmeyi ihmal etmemektedir. "İyi" den pay almak isteyen kimse için problemler sadece tanımlama yaparak irdelenemez. Felsefeci, "nedir?” sorusunu sorduğu kadar "ne için?" sorusunu da önemsemelidir. (Aristoteles/Çev, 2017)

\section{2. İslam'da Mutluluğun Anlami:}

İslâm düşünce tarihinde mutluluk konusunu detaylı bir şekilde ele alan, mutluluğu meşhur bir amaç olarak gören Farabi (870-950), her ne zaman olursa olsun başka bir şey için değil bizzat kendisi için istenilen, tercih edilen bir gaye olduğunu, mutluluğa ulaşıldığında, onunla birlikte ondan başka hiçbir şeye ihtiyaç kalmayacağını düşünmektedir. (Özcan, 1993) Farabî felsefesinde ahlâkın mutluluğun alt konusu olduğunu söyleyebiliriz. Her ne kadar kategori olarak mutluluğun yeri metafizik bir nihai amaç olarak ahlâktan farklı bir yerde olsa da, ahlâk da mutluluğa ulaşılma usûlü olarak onunla iç içedir. Dolayısıyla mutluluk ahlâkın amacıdır. (Bolay, 2009) O mutluluğu insan ruhunun vücutta, maddeye ihtiyaç hissetmeyecek bir tekâmül mertebesine ulaşması olarak tanımlamaktadır. Bir başka ifadeyle mutluluk insan nefsinin maddeye muhtaç olmayacak ssekilde yetkin olmasıdır.Farabi bu yetkinliği "Nihai Mutluluk/es-Saadetu'l-Kusva" olarak isimlendirmektedir. Farabi mutluluğu en büyük hayır ve en büyük fazilet olarak kabul ettiği için onun dişındaki her şeyin sadece mutluluğa ulaştıracak araçlar olduğu görüşündedir. Bu sebeple mutluluk hayır için yapılan hayırdır ve hiçbir zaman hayırdan başka şeyler için istenmemektedir. Dolayısıyla kişiyi mutluluğa ulaştıran kendi güzel eylemleridir. Mutluluğa engel olan ise düşüklük, rezillik, hasislik gibi kötülük içerikli eylemlerdir. Farabi’ye göre dünya ve ahiret mutluluğu sadece ve sadece erdemler vasitasiyla elde edilebilmektedir. (FARABİ, 2001) (Farabi/Çev.Özcan.H, 1987) (FARABİ/Çev, 2018)

Mutluluğun bu dünyada bizzat kendinde bir gaye olmadığını; mutluluktan gayenin Allah'ın sevgisini kazanmak olduğunu ve dünyevi yaşamda mutluluğun iki seviyesi arasında ayrım yapılabileceğini görmüş bulunuyoruz: Birincisi, psikolojik ve kalıcı olmayan, geçici insan hallerini tanımlar. Bu mutluluk hali, hisler ve duygular olarak tanımlanabilir ve istekler ve ihtiyaçlar faziletlere uygun doğru davranışlarla gerçekleştirilmeye çalışıldığında elde edilir. İkincisi ruhsal ve kalıcı olan, bilinçli bir şekilde tecrübe edilen ve dünyevi yaşamın üzerine oturduğu bir seviyedir. Bu seviye, şans ya da bedbahtlık olarak yüzünü gösteren birçok olaydan sonra, insanın davranış biçimini ve faziletli faaliyetlerini test eden bir deneme süreci sonucunda elde edilir; başka bir ifadeyle, ne bahtiyarlığı kendisini hataya sürükler ne de bedbahtlığı onu acı bir bozguna uğratır. Elde edildiğinde bu ikinci seviye, ihtiyaçların azalması ve ihtiyaçların karşılanması hariç, birinci ile aynı anda gerçekleşir.Mutluluğun bu 
ikinci seviyesi, en yüksek aşaması ahirette Allah'in cemalini görmek olan bir üçüncü seviyedeki mutluluğun ön hazırlığıdır. Çağlar boyunca gerçek müminlerin bilincinde, mutluluğun bu anlamı ve deneyimi konusunda herhangi bir değişme olmamıştır. (DÜZGÜN P. e.-A., 2011) İbn Sînâ, mutluluğu dinî ve metafiziksel anlamda kişinin yetkinliğe ulaşmas1 olarak tanımlamıștır. Akli ve ruhi bir anlam yüklenen mutluluk, ancak bilgi ve hikmetle mümkündür. Bu da ancak bu dünyada erdemlerin gerçekleşmesiyle olur. Davranışlarında erdemi gözeten insanlar faal akılla bağlantı kurarak gerçek mutluluğa ulaşırlar. (ÇAĞRICI, 2008) İbn Sînâ'ya göre insan mutluluğa ulaşmak için gerçek mutluluk ve hazları bilmelidir. Çünkü geçici hazlar kusurlu olduğu için insana çirkinlik bulaştırır. Bu bağlamda insanın mutlu olmasinı engelleyen, cehaletidir. Kendi nefsini bilmeyen insan, herhangi bir bedensel kayıp yaşadığında üzüntü duyar. (Toktaş, 2011)

İbn Hazm da dünyanın gelip geçici, oluş ve bozuluşa maruz kaldığını vurgulayan müellifler arasındadır. Bu yüzden o düşüncenin nihai noktasında kişinin yalnızca ahireti diğer bir ifadeyle Allah'ın rızası için çalışması gerektiğini belirterek dünyada dünyalık için gerçekleştirilen her hedefin akabinde hüznün saklı olduğunu beyan etmektedir. Kişinin Allah'ın rızasını öncelemesi dünya ve ahiret için mutluluk vesilesi olacağı gibi dünyadaki mutluluğun sebebini ise "çoğu insanın kaygı duyduğu şeyler karşısında senin fazla kaygı duymamandır.” (Hazm, 2019) (Yakub bin İshak el-Kindi, 2014)

\subsection{Kur'an-1 Kerim'de mutluluk ilgili ayetleri:}

26. Allah, rızkı dilediğine bol verir, (dilediğine de) kısar. Onlar ise dünya hayatı ile sevinmektedirler. Hâlbuki dünya hayatı, ahiretin yanında çok az bir yararlanmadan ibarettir. (RA'D SÛRESI)

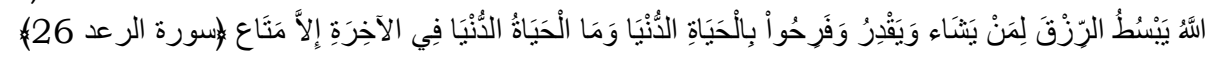

18. "Küçümseyerek surat asıp insanlardan yüz çevirme ve yeryüzünde böbürlenerek yürüme! Çünkü Allah, hiçbir kibirleneni, övüngeni sevmez. (LOKMÂN SÛRESİ)

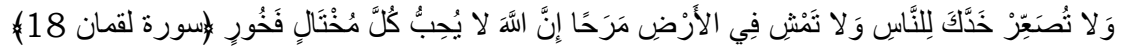

20. Bilin ki, dünya hayatı ancak bir oyun, bir eğlence, bir süs, aranızda karşıllklı bir övünme, çok mal ve evlat sahibi olma yarışından ibarettir. (Nihayet hepsi yok olur gider). Tipkı şöyle: Bir yağmur ki, bitirdiği bitki çiftçilerin hoşuna gider. Sonra kurumaya yüz tutar da sen onu sararmış olarak görürsün. Sonra da çer çöp olur. Ahirette ise (dünyadaki amele göre ya) çetin bir azap ve(ya) Allah'ın mağfiret ve rızası var. (HADÎD SÛRESİ)

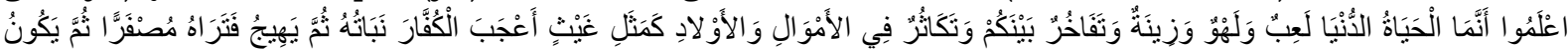

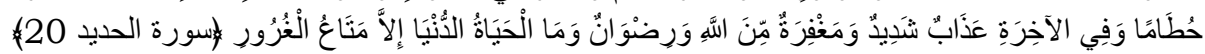

69. (Ey münafıklar!), siz de tıpkı sizden öncekiler gibisiniz: Onlar sizden daha güçlü, malları ve çocukları daha fazlaydı. Onlar paylarına düşenden faydalanmışlardı. Sizden öncekilerin, paylarına düşenden faydalandığı gibi siz de payı nıza düşenden öylece faydalandınız ve onların daldığı gibi, siz de (dünya zevkine) daldınız. İşte onların dünyada da ahirette de amelleri boşa gitmiştir. İşte onlar ziyana uğrayanların ta kendileridir. (TEVBE SÛRESİ) (ŞAHİN, 2011)

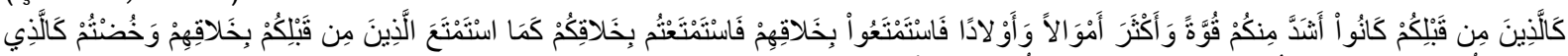

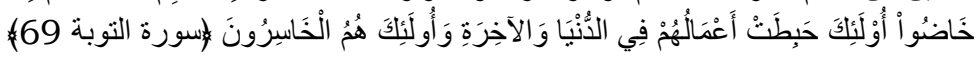

32.Dünya hayatı bir oyun ve eğlenceden başka bir şey değildir.Muttakî olanlar için ahiret yurdu muhakkak ki daha hayırlıdır. Hâla akıl erdiremiyor musunuz? ( EN'ÂM SÛRESİ)

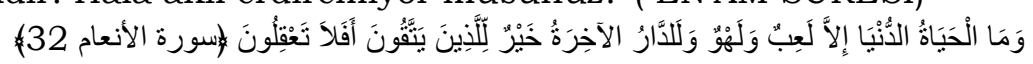

171.Onlar, Allah' tan gelen nimet ve keremin; Allah' in, müminlerin ecrini zayi etmeyeceği müjdesinin sevinci içindedirler. (ÂL-I İMRÂN SÛRESİ)

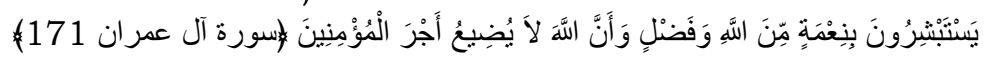


1.Biz senin göğüsünü açıp genişletmedik mi? (EL-İNŞIRÂH SÛRESİ) (Ali Özek, 2012)

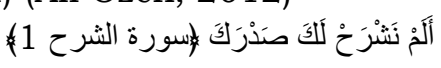

25. Mûsâ dedi ki: "Gönlüme genişlik ver, Rabbim. (TÂHÂ SÛRESI)

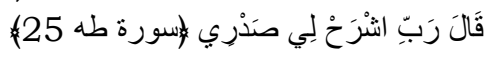

4. İmânlarına îmân katmak için mü'minlerin kalblerine sükûnet ve emniyet indiren O'dur. Göklerin ve yerin orduları Allah'indır. Allah, her şeyi hakkıyla bilir, her işi hikmetle yapar. (FETIH SÛRESI)

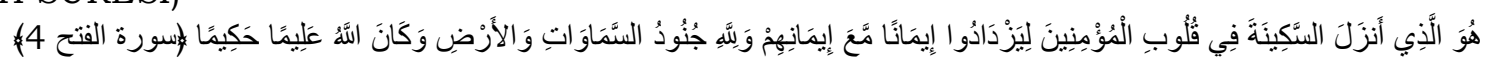

5. Ve elbette Rabbin sana râzı olacağın ihsanlarda bulunacaktır. (DUHÂ SÛRESI)

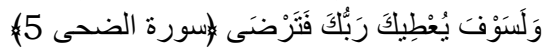

28. Onlar, îmân eden ve kalbleri Allah'in zikriyle huzur bulan kimselerdir. Haberiniz olsun ki, kalbler ancak Allah'nzzikriyle huzura kavuşur. (RA'D SÛRES) (İhsan Atasoy, Mart 2012)

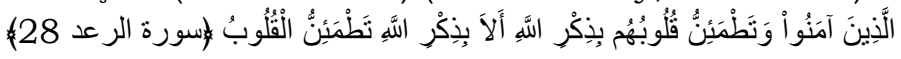

120 .Size bir iyilik dokunsa (bu), onları tasalandırır; size bir kötülük dokunsa, ondan ötürü sevinirler. Eğer sabreder, korunursanız onları n hilesi size hiçbir zarar veremez. Şüphesiz Allah, pnların yaptıklarını kuşatmıștı $r$ (onların tuzaklarını, hilelerini sizden sayar, onların yaptığı her şeyi bilir). (ÂL-I İMRÂN SÛRESİ)

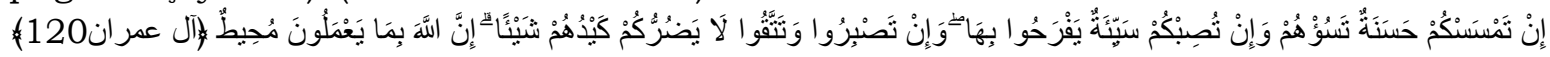

170 .Allah'ın, keremiyle kendilerine verdiklerinden sevinçli olarak, arkaları ndan henüz (şehid olup) kendilerine yeti şemeyenlere de korku olmadığı, onları $\mathrm{n}$ da üzüntüye uğramayacakları müjdesiyle sevinmektedirler. (ÂL-I İMRÂN SÛRESİ)

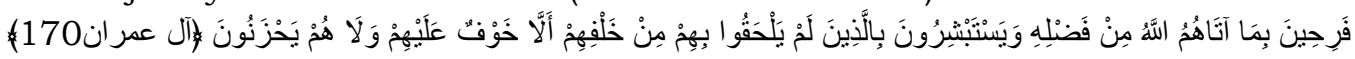

188.O ettiklerine sevinen, yapmadıkları şeyerle övülmeyi sevenlerin, azâbdan kurtulacaklarını sanma. Onlar için acı bir azâb vardır. (ÂL-I İMRÂN SÛRESİ)

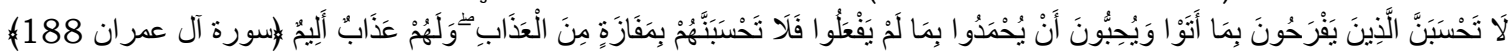

36. Derken şeytan, onların (ayağını) oradan kaydırdı, içinde bulundukları(nimet yurdu)ndan çıkardı. (Biz de) dedik ki : "Birbirinize düşman olarak inin. Sizin yeryüzünde kalıp bir süre yaşamanız lâzımdır." (BAKARA SURESI)

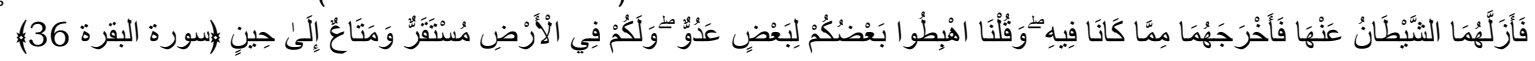

126. İbrahim demişti ki :"Rabbim, bu şehri güvenli bir şehir yap, halkından Allah'a ve âhiret gününe inananları çeşitli ürünlerle besle!" (Rabbi) buyurdu ki : " İnkâr edeni dahi az bir süre geçindirir, sonra onu cehennem azâbına (girmeğe, mecbur ederim. Ne kötü varılacak yerdir oras1!" (BAKARA SURESI)

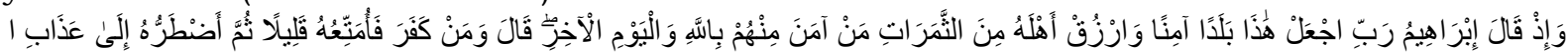

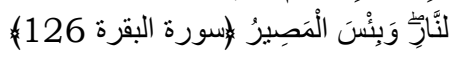

236. Henüz dokunmadan, ya da bir mehir kesmeden kadınları boşarsantz, size bir günah yoktur. Onları faydalandırın (yani bir miktar bir şey verin). Eli geniş olan, kendi gücü nisbetinde, eli dar olan da kendi kaderince güzel bir şekilde faydalandırmalı (herkes gücü ölçüsünde bir şey vermeli) dir. Bu, iyilik edenlerin üzerine bir borçtur. (BAKARA SURESI)

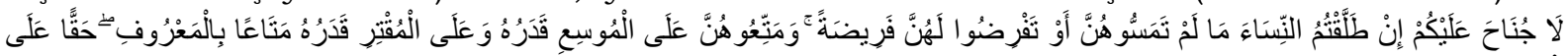

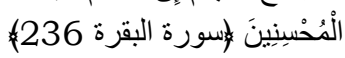

241.Boşanmış kadınların uygun olan geçimlerini sağlamak, (Allah'ın azâbından) korunanlar üzerine bir borçtur. (BAKARA SURESI)

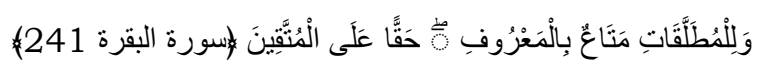

14. Kadınlardan, oğullardan, kantarlarca yığılmış altun ve gümüşten, salma atlardan, davarlardan ve ekinlerden gelen zevklere aşırı düşkünlük, insanlara süslü (câzib) gösterildi. 
Bunlar, sadece dünya hayatının geçimidir. Asıl varılacak güzel yer, Allah'ın yanındadır.( Al-i İmran Suresi)

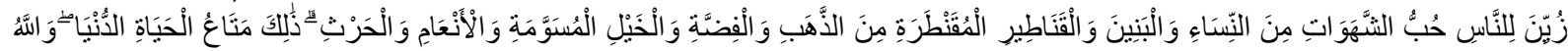

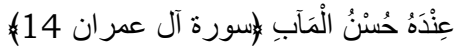

185. Her cân ölümü tadacaktır. Kıyamet günü ecirleriniz, size eksiksiz verilecektir. Kim ki hemen ateşin elinden kurtarılır da cennete sokulursa, işte o, kurtuluşa ermiştir. Dünya hayat1, aldatıc1 zevkten başka bir şey değildir. (Al-i İmran Suresi)

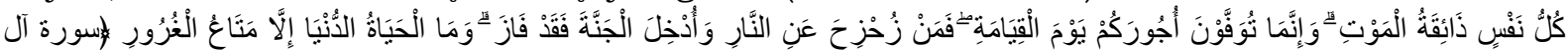
عمران 185

24.(Savaşta esir olarak) ellerinize geçen(câriye)ler müstesnâ, evli kadınlar (la evlenmeniz) de (haramdır. İşte bunlar) size Allah'ın yazdığı yasaklardır. Bunlardan ötesini, iffetli yaşamak, zinâ etmemek şartiyle mallarınızla istemeniz (mehirlerini verip almanız), size helâl kılındı. O halde onlardan ne kadar yararlandınızsa, ona karş1lık kesilen ücretlerini bir hak olarak verin. Hakkın (mehrin) kesiminden sonra karş111klı anlaşmak (suretiyle kesilenden az veya çok vermeniz) de üzerinize bir günah yoktur. Şüphesiz Allah, (herşeyi) bilendir, yerli yerince yapandır. (Nisâ' Suresi) (ATEŞ, 1982)

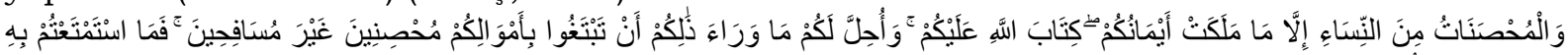

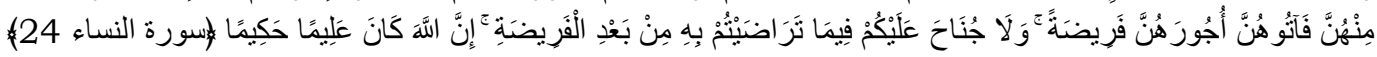

44.Derken onlar kendilerine hatırlatılanı unuttuklarında, (önce) üzerlerine her şeyin kapılarını açtık. Sonra kendilerine verilenle sevinip şımardıkları sırada onları ansızın yakaladık da bir anda tüm ümitlerini kaybedip yıkıldılar. En'âm SÛRESİ

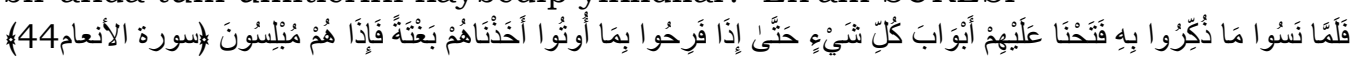

50.Sana bir iyilik gelirse, bu onları üzer. Eğer başına bir musîbet gelirse, "Biz tedbirimizi önceden almıştık" derler ve sevinerek dönüp giderler. TEVBE SÛRESİ

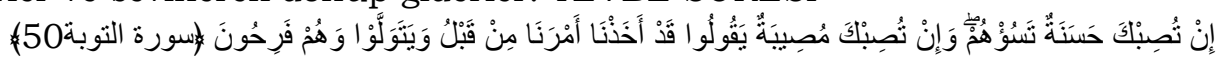

81.Allah'ın Resûlüne karşı gelerek (sefere çıkmayıp) geri bırakılanlar, oturup kalmalarına sevindiler. Allah yolunda mallarıla canlarıla cihad etmek hoşlarına gitmedi ve "Bu sicakta sefere çıkmayın" dediler. De ki: "Cehennemin ateşi daha sıcaktır." Keşke anlasalardı. TEVBE SÛRESI

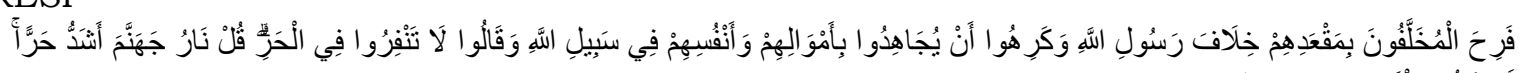

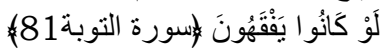

10.Ama kendisine dokunan bir sikıntıdan sonra, ona bir nimet tattırırsak mutlaka, "Kötülükler benden gitti" diyecektir. Çünkü o şımarık ve böbürlenen biridir. HÛD SÛRESİ

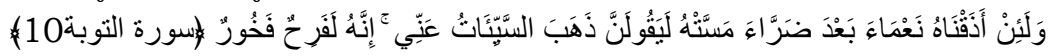

36.(Elçilerin sözcüsü) Süleyman'ın huzuruna gelince, Süleyman ona şöyle dedi: "Siz beni mal ile desteklemek (ve böylece etkilemek) mi istiyorsunuz? Oysa Allah'ın bana verdiği size verdiğinden daha hayırlıdır. Fakat hediyenizle ancak siz sevinirsiniz." NEML SÛRESI

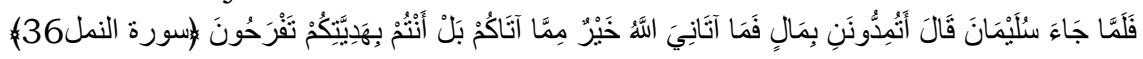

83. Peygamberleri onlara apaçık deliller getirince, sahip oldukları bilgi ile şımardılar (ve onları alaya aldılar). Sonunda alaya almakta oldukları şey kendilerini sarıverdi. Mü'min Sûresi

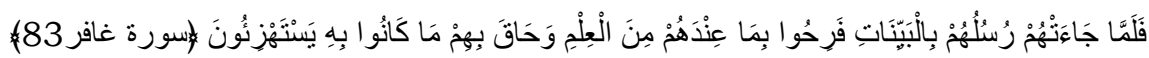

23.Elinizden çıkana üzülmeyesiniz ve Allah'ın size verdiği nimetlerle şımarmayasınız diye (böyle yaptık.) Çünkü Allah, kendini beğenip övünen hiçbir kimseyi sevmez. HADÎD SÛRESİ

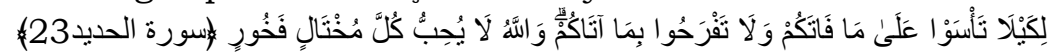

75.Bu, sizin yeryüzünde haksız yere şımarmanızdan ve böbürlenmenizden ötürüdür. MÜ'MIN SÛRESI 


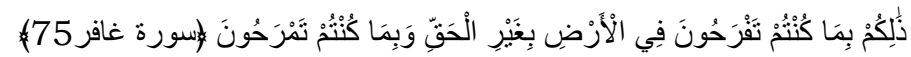
196.Hacc1 da, umreyi de Allah için tamamlayın. Eğer (düşman, hastalık ve benzer sebeplerle) engellenmiş olursanız artık size kolay gelen kurbanı gönderin. Bu kurban, yerine varıncaya kadar başlarınızı tıraş etmeyin. İçinizden her kim hastalanır veya başından rahatsız olur (da tıraş olmak zorunda kalır)sa fidye olarak ya oruç tutması, ya sadaka vermesi, ya da kurban kesmesi gerekir. Güvende olduğunuz zaman hacca kadar umreyle faydalanmak isteyen kimse, kolayına gelen kurbanı keser. Kurban bulamayan kimse üçü hacda, yedisi de döndüğünüz zaman (olmak üzere) tam on gün oruç tutar. Bu (durum), ailesi Mescid-i Haram civarında olmayanlar içindir. Allah'a karşı gelmekten sakının ve Allah'ın cezasının çetin olduğunu bilin. BAKARA SÛRESI

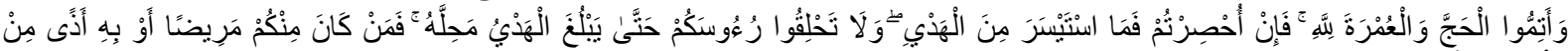

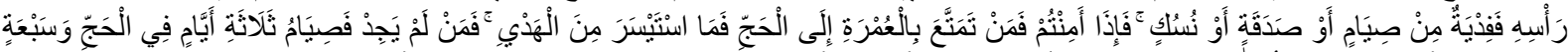

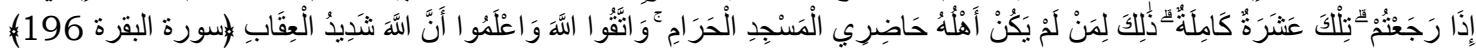

8.İnsana bir zarar dokunduğu zaman Rabbine yönelerek O'na yalvarır. Sonra kendi tarafından ona bir nimet verdiği zaman daha önce ona yalvardığını unutur ve Allah'ın yolundan saptırmak için O'na eşler koşar. De ki: "Küfrünle az bir süre yaşayıp geçin! Şüphesiz sen cehennemliklerdensin." ZÜMER SÛRESI

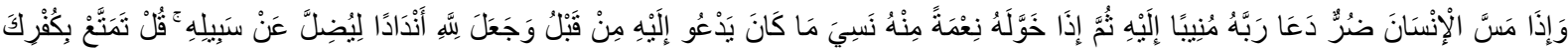

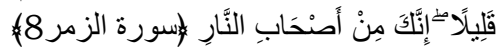

77.Daha önce kendilerine, "(savaşmaktan) ellerinizi çekin, namazı kılın, zekâtı verin" denilenleri görmedin mi? Üzerlerine savaş yazıllnca hemen içlerinden bir kısmı; insanlardan, Allah'tan korkar gibi, hatta daha çok korkarlar ve "Rabbimiz! Niçin bize savaş yazdın? Bizi yakın bir zamana kadar erteleseydin ya!" derler. De ki: "Dünya geçimliği azdır. Ahiret, Allah'a karşı gelmekten sakınan kimse için daha hayırlıdır. Size kıl kadar haksızlık edilmez." NİSÂ SÛRESI

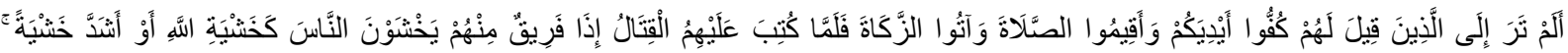

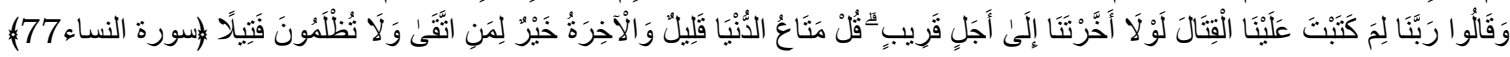

3." Rabbinizden bağışlanma dileyin, sonra da O'na tövbe edin ki sizi belirlenmiş bir süreye (ömrünüzün sonuna) kadar güzel bir şekilde yararlandırsın ve her fazilet sahibine faziletinin karşılığını versin. Eğer yüz çevirirseniz, ben sizin adınıza büyük bir günün azabından korkuyorum. HÛD SÛRESİ

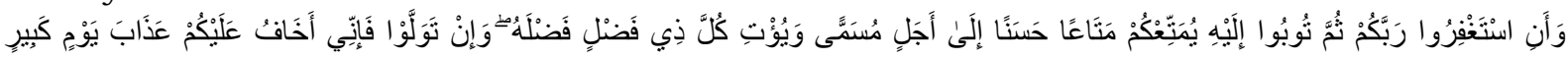

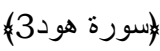

69.(Ey münafıklar!), siz de tıpkı, sizden öncekiler gibisiniz: Onlar sizden daha güçlü, malları ve çocukları daha fazlaydı. Onlar paylarına düşenden faydalanmışlardı. Sizden öncekilerin, paylarına düssenden faydalandığ gibi siz de payınıza düşenden öylece faydalandınız ve onların daldığı gibi, siz de (dünya zevkine) daldınız. İște onların dünyada da ahirette de amelleri boşa gitmiştir. İşte onlar ziyana uğrayanların ta kendileridir. TEVBE SÛRESİ

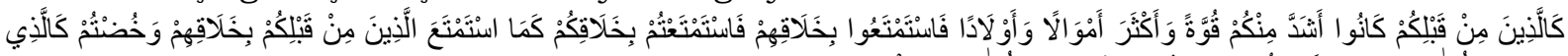

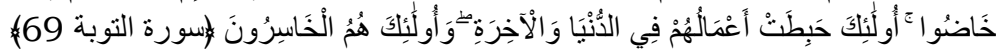

36.Şüphesiz dünya hayatı ancak bir oyun ve eğlencedir. Eğer inanır ve Allah'a karş1 gelmekten sakınırsanız, O size mükafatınızı verir ve sizden mallarınızı (tamamen sarf etmenizi) istemez. Muhammed Sûresi

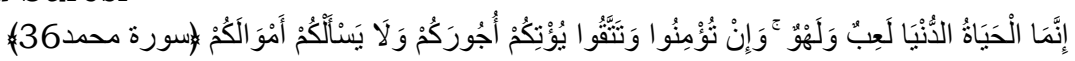

70.Dinlerini oyun ve eğlence edinenleri ve dünya hayatı kendilerini aldatmış olanları bırak. Hiç kimsenin kazandığ1 yüzünden mahrumiyete sürüklenmemesi için Kur'an ile öğüt ver. Yoksa ona Allah'tan başka ne bir dost vardır, ne de bir şefaatçi. (Kurtuluşu için) her türlü fidyeyi verse de bu ondan kabul edilmez. İște onlar kazandıkları yüzünden helake sürüklenmiş kimselerdir. Küfre saplanıp kalmalarından dolayı onlara çılgınca kaynamış bir içecek ve elem dolu bir azap vardır. En'âm Sûresi 


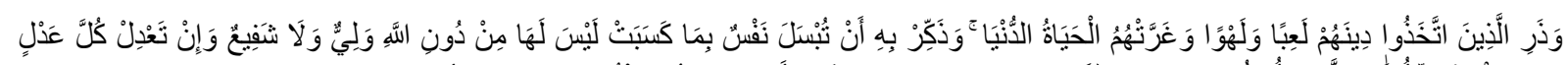

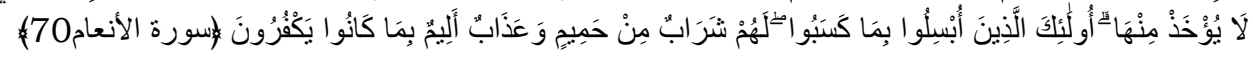

51.Onlar dinlerini oyun ve eğlence edinmişler ve dünya hayatı da kendilerini aldatmıştı. İşte onlar bu günlerine kavuşacaklarını nasıl unuttular ve âyetlerimizi nasıl inkar edip durdularsa biz de onları bugün öyle unuturuz. A'RÂF SÛRESI (Hayreddin Karaman .. G., 2020)

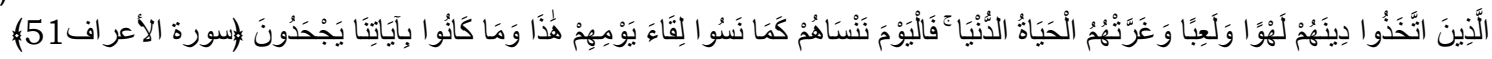

3.Bırak onları, yesinler, geçinsinler ve isteklere düşüp oyalansınlar, yakında bilecekler. HİCR SÛRESI

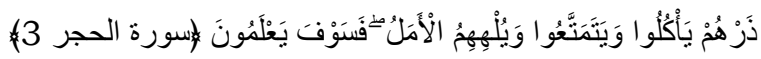

2.Rablerinden, Kur'an'a ait yeni bir ayet geldi mi onu alaya alarak dinlerler, oyun sanirlar. ENBIYYÂ SÛRESİ

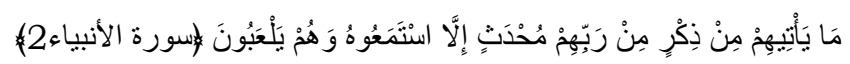

3. Kalpleri de oyuna dalmıştır da o zalimler, fisıltıyla konuşarak bu da sizin gibi bir insandan başka bir mahluk mu ki, göz göre göre büyüye mi kapılacaksınız derler. ENBiYÂ SÛRESI

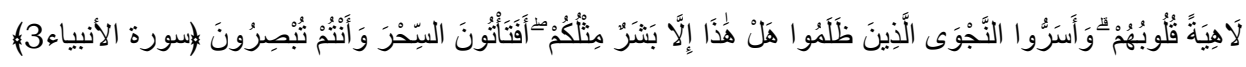

17.Eğlence için bir kadın edinmek isteseydik kendi katımızdakilerden edinirdik, fakat biz, böyle bir şey yapmayız. ENBIYYÂ SÛRESİ

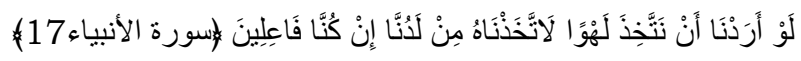

37. Öyle erler vardır ki onları ne ticaret, ne alımsatım, Allah'ı anmaktan ve namaz kılmaktan ve zekat vermekten alıkoymaz, gönüllerin ve gözlerin döneceği günden korkar onlar. NÛR SÛRESI

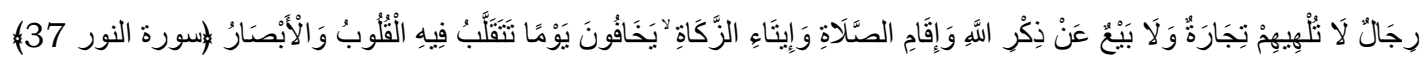

260. An o zamanı da, hani İbrahim, Rabbim demişti, ölüyü nasıl diriltirsin? Allah, inanmıyor musun demişti de İbrahim, evet, inanıyorum ama kalbim tam yatışsın, iyice anlayayım demişti. Allah da demiştiki: Dört kuş al, onları kesip paramparça et, parçalarını birbirine kat, sonra o karışık parçalardan her birini bir dağın üstüne koy, sonra da onları çağır, koşarak sana gelecekler. Bil ki Allah, şüphe yok ki pek yücedir, hikmet sahibidir. BAKARA SÛRESI

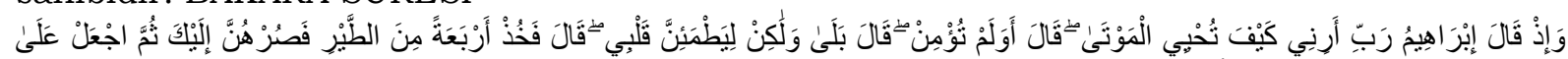

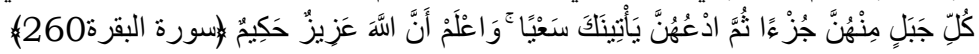

126. Allah, bunu ancak size bir müjde olsun da yürekleriniz yatışsın diye yapmıştır ve yardım, ancak hüküm ve hikmet sahibi Allah'tandır. ÂL-İ İMRÂN SÛRESİ

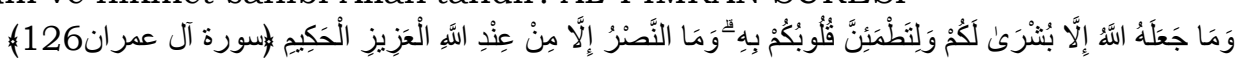

103. Namazı kıldıktan sonra ayaktayken, otururken ve yanınıza yaslanınca Allah'ı anın, tam emniyete ve huzura ulaşınca da namazı dosdoğru kılın, çünkü namaz, müminlere muayyen vakitlerde kılınmak üzere farz edilmiştir. NíSÂ SÛRESİ (Gölpınarlı, 2007)

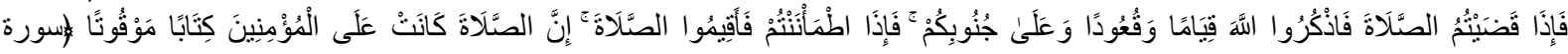

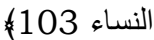

10. Allah bunu yalnızca bir müjde olsun ve kalpleriniz yatışsın diye yapmıştı, yardım ise yalnız Allah katındandır. Muhakkak Allah Azîz'dir, Hakîm'dir. ENFÂL SÛRESİ

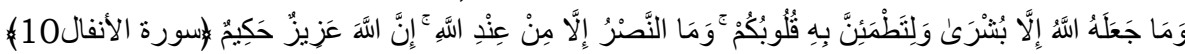

112.Allah, (ibret için) bir ülkeyi örnek verdi: Bu ülke güvenli, huzurlu idi; ona rızkı her yerden bol bol gelirdi. Sonra onlar Allah'ın nimetlerine karşı nankörlük ettiler. Allah da onlara, yaptıklarından ötürü açlık ve korku sıkıntısını tattırdı. NAHL SÛRESİ 


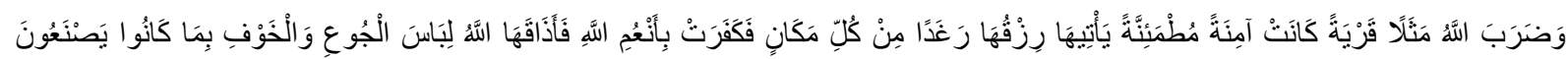

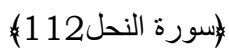

11.İnsanlardan kimi Allah'a yalnız bir yönden kulluk eder. Şöyle ki: Kendisine bir iyilik dokunursa buna pek memnun olur, bir de musibete uğrarsa çehresi değişir (dinden yüz çevirir). $\mathrm{O}$, dünyasını da, ahiretini de kaybetmiştir. İşte bu, apaçık ziyanın ta kendisidir. HAC SÛRESI

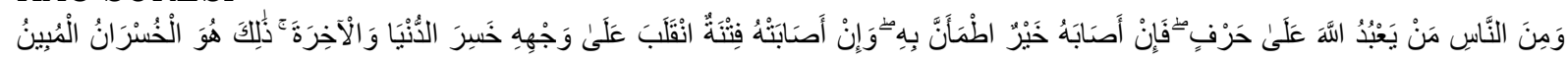

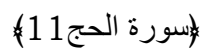

16. Allah kendi rızasına uyan kimseyi onunla selamet yollarına iletir ve onları izniyle karanlıklardan nura çıkarır ve onları dosdoğru bir yola iletir. MÂIDE SÛRESİ

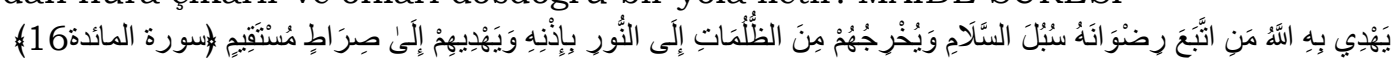

18. Andolsun, Allah, sana o ağacın altında biat ederlerken mü'minlerden razı olmuştur, kalplerinde olanı bilmiş ve böylece üzerlerine güven duygusu ve huzur indirmiş ve onları yakın bir fetih ile mükafatlandırmıştır. FETIH SÛRESI

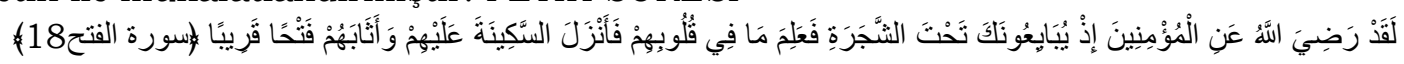

29. Muhammed, Allah'ın Rasulü'dür. Ve onunla birlikte olanlar da kafirlere karşı sert ve kat1, kendi aralarında ise merhametlidirler. Onları, rüku edenler, secde edenler olarak görürsün; onlar, Allah'tan bir lütuf ve hoşnutluk arayıp-isterler. Belirtileri, secde izinden yüzlerindedir. İşte onların Tevrat'taki vasıfları budur; İncil'- deki vasıfları ise: Sanki bir ekin; filizini çıkarmış, derken onu kuvvetlendirmiş, derken kalınlaşmış, sonra sapları üzerinde doğrulup-boy atmış, ekicilerin hoşuna gider. Onunla kafirleri öfkelendirmek içindir. Allah, içlerinden iman edip salih amel işleyenlere bir mağfiret ve büyük bir ecir va'detmiştir. FETİH SÛRESİ

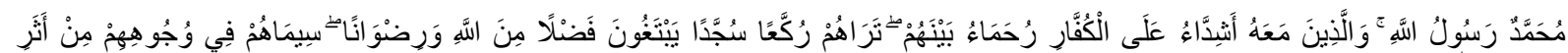

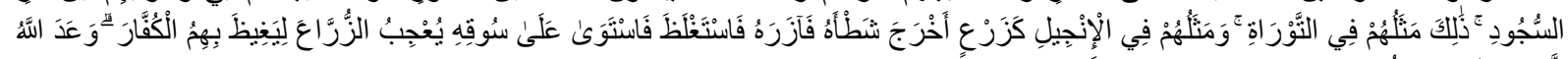

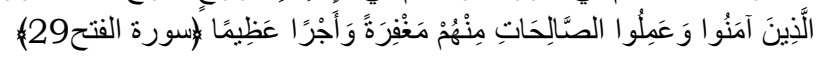

22 .Allah'a ve ahiret gününe iman eden hiç bir kavmin, Allah'a ve Rasulü'ne başkaldıran kimselere -babaları, oğulları, kardeşleri veya aşiretleri olsa bile- sevgi beslediklerini göremezsin. Kalplerine imanı yazmış ve kendisinden bir ruh ile onları desteklemiştir. Onları, altından nehirler akan cennetlere sokacaktır; orada süreklidirler. Allah, onlardan razı olmuş, onlar da O'ndan razı olmuşlardır. İşte bunlar Allah'ın fırkasıdır. Dikkat edin şüphesiz Allah'in firkası kurtuluşa erenlerin kendileridir. MÜCÂDELE SÛRESİ

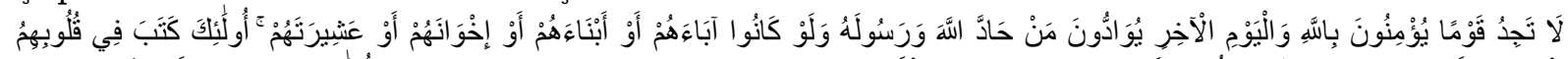

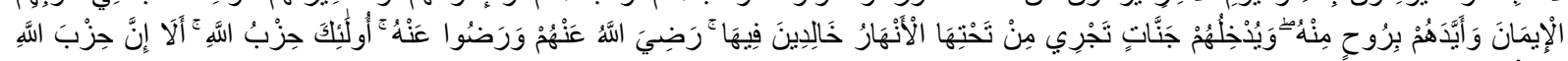

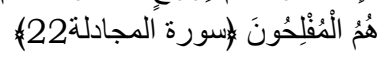

27.Sonra onların izleri üzere rasullerimizi birbiri ardınca gönderdik. Arkalarından da Meryem oğlu İsa'yı gönderdik; ona İncil'i verdik ve onu izleyenlerin kalplerine bir şefkat ve merhamet koyduk. Allah'ın rızasını kazanmak için türettikleri fakat gereği gibi uymadıkları ruhbanlığ onlara gerekli kilmadık. Bununla birlikte onlardan iman edenlere ödüllerini verdik, onlardan bir çoğu da fasıklardır. HADÎD SÛRESİ (Şems, 2011)

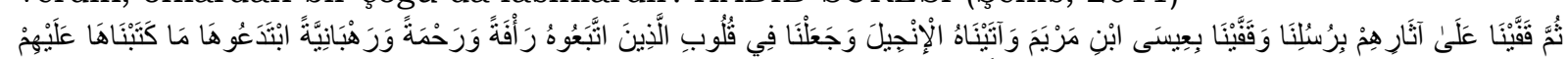

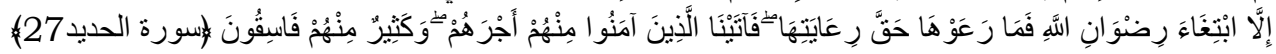

\section{Sonuç}

İnsan, mutluluk arayışında ve hatta mutluluk peşinde koşan ve hayatta belki de gerçek amacının mutlu olmak olduğuna inanan bir varlıktır. Ya hayatında bulduğu bir anlamdan dolayı kendini mutlu hisseder ya da ona kendini mutlu hissettiren şeyler hayatına anlam katar. Mutluluk ve anlam birbiriyle iç içe geçmiş ve birbiriyle yakından bağlı iki duygu durumudur durumdur.İnsan, bu sevgi ve şefkatini paylaşacağ diğer insanlara veya 
canlılara ihtiyaç duyar. Mutluluğun tanımı felsefe ve hikmet okullarının temel meselesi olduğu gibi, dini ve mistik geleneklerin de üzerinde söz söylediği temel mevzular arasındadır.Müslüman filozoflar mutluluğu çeşitli şekillerde tarif etmeye çalışmışlardır.İlk filozoflardan Kindî, onun mutluluğu iki kısma ayırmış olmasıdır. Bunlardan ilki dokunma, duyma, yeme, içme gibi geçici ve sonrasında eziyet ve cefanın geldiği duyusal mutluluk, diğeri de uhrevi diyebileceğimiz şeref ve yüceliğe vesile olan ilahî mutluluktur.Fârâbî’ye göre ise mutluluk, "insan ruhunun varlık bakımından kendisine dayanacağı bir maddeye ihtiyaç duymayacağı bir mükemmellik derecesine ulaşmasıdır".

O halde mutluluğu gaye olarak değerlendiren İslam filozoflarının, insanın duygusal varlığını aşan ve dünyevi olmayan bir gayeden bahsettikleri anlaş1lmaktadır. mutlulukla ilgili tariflerinde göze çarpan diğer önemli bir husus da, mutluluğun birbirini gerektiren iki temel özelliğinin olmasıdır. Bunlardan ilki, mutluluğun her zaman sadece kendinden dolayı tercih edilmesidir. İkincisi ise, mutluluğun kendi kendine yeterli oluşudur .İşte mutluluk, bu özelliklerinden dolayı bütün ahlakî davranışların temel gayesi konumuna yükselmekte ve böylece Müslüman düşünürlerce ahlakî değerler mutluluğa göre belirlenmektedir. İnsanın başına iyi şeyler geldiği kadar kötü şeyler de gelebilir. Karanlık da bizim içindir, aydınlık da. İnsan başına ne gelirse gelsin, yetinmeyi hayat felsefesi hâline getirirse mutluluğa ulaşacaktır. Fakat en iyi durumda iken bile şikâyette bulunan insanları hiçbir şey mutlu edemez. Onlar, içinde bulundukları her durumun olumsuz yanlarını görerek başlarına gelen kötü şeyleri en kötüsü olarak düşünür ve tüm kötülüklerin sadece kendisine uğradığına inanırlar. Bu bakış açısına sahip bir insanın başına dünyanın en güzel şeyi de gelse, mutlu olması imkânsızdır. Bu çerçevede bu çalışmanın amacına ulaştığı kanısında olunup, bundan sonra bu konularda yapılacak çalışmalara kaynaklık edeceği umut edilmektedir.

\section{Kaynakça}

Acaboğa, A. (2007). Din ve Mutluluk İlişkisi/ s.15. Türkiye-Kahramanmaraş: Kahramanmaraş Sütçü İmam Üniversitesi. Sosyal Bilimler Enstitüsü /Basılmamış Yüksek Lisans Tezi.

Akarsu, B. (1982). Ahlak Öğretileri/ss.84-91. İstanbul: Remzi Kitabevi. Akbaş, M. E. (2019). Gerçek Mutluluk/15-19. İstanbul: Eksi Kitaplar.

Ali Özek, H. K. (2012). KURÂN-I KERÎM VE TÜRKÇE AÇIKLAMALI TERCÜMESİ - MEÂLİ

/En'âm/Âl-i İmrân/El-İnşirâh. Medine-i Münevvere: Suud Hac ve Evkaf Bakanlığı.

Aristoteles/Çev, S. B. (2017). Eudemos'a Etik/s. 16. Ankara: BilgeSu Yayıncılık. ATEŞ, P. D. (1982). KUR'AN-I KERNİ N YÜCE MEM] VE ÇAĞDAŞ TEFSiRİ/ Birinci Cilt /. ANKARA: ANKARA ÜNIVERSITESI ILAHIYAT FAKÜLTESI YAY İNLAR.

Bolay, S. H. (2009). Felsefe Doktrinleri ve Terimleri Sözlüğü/s.256. Ankara: Nobel Yayınları. Bora, S. W. (2014). Mutsuz Olmak- Bir Yüreklendirme/s.67. İstanbul: İletişim Yayınları.

ÇAĞRICI, M. (2008). "Saadet" Maddesi/Türkiye Diyanet Vakfı İslam Ansiklopedisi (DİA)/ s. 321. İstanbul: Türkiye Diyanet Vakfı İslam Araştırmaları Merkezi.

CEVIZCI, A. (1997). FELSEFE SÖZLÜĞÜ /ss.612-613. İstanbul: Paradigma.

Derinsu, M. U. (1986). Yaşamın Trajik Duygusu/s.100. İstanbul: İnkılap Kitabevi.

DÜZGÜN, P. D.-A. (2007). IX. KUR'AN SEMPOZYUMU Kur'an'da Ahlaki Değerler/islam'da Mutluluğun Anlami Ve Yaşanmast/s.38. ANKARA: Fecr Yayınları:98.

DÜZGÜN, P. e.-A. (2011, 9 2). İSLAM'DA MUTLULUĞUN ANLAMI VE TECRÜBES/ss.235-

236. Kelam Araştırmaları Sanal Dergisi, s. SS.219-238.

Eyupoğlu, M. /. (1997). Düşünceler/s.240. İstanbul: Cem Yayınevi.

FARABİ. (2001). el-Medinetü'l-fâzıla/ss.69-70. Ankara: Milli Eğitim Bakanlığı.

FARABİ/Çev, A. (2018). Mutluluğun kazanılması/s.1. İstanbul: Türkiye İş Bankası.

Farabi/Çev.Özcan.H. (1987). Fususu' 1-medenî/s.39. izmir: Dokuz Eylül Üniversitesi.

Gölpınarl1, A. (2007). Kur'an-1 Kerim ve Meali. İstanbul: Elif Kitabevi. 


\section{HAPPINESS A QURANIC PERSPECTIVE}

Hayreddin Karaman, .. G. (2020). Kur'an Yolu Türkçe Meal ve Tefsir. Ankara: Diyanet İşleri Başkanlığ1 .

Hayreddin Karaman, .. G. (2020). Kur'an Yolu Türkçe Meal ve Tefsir. Ankara: Diyanet İşleri Başkanlığ1.

Hazm, İ. (2019). Ahlâk ve Davranış Tarzları Nefislerdeki Ahlâkî Hastalıkların Tedavisi/3-4. Ankara: TDV Yayınları.

Hünler, A. M. (2001). Ethik'in Kısa Tarihi/s.28. İstanbul: Paradigma Yayınlar1.

İhsan Atasoy, Ü. Ş. (Mart 2012). Kur'an-1 Kerim Meali/Tâhâ Sûresi/Fetih Sûresi/Duhân Sûresi/Ra'd Sûresi. İstanbul: Nesil Basim.

Mayadağ, S. A. (31.05.2016). The Promise of Happiness-Mutluluk Vaadi/s.16. İstanbul: SEL YAYINCILIK.

Özcan, F. (1993). MUTLULUK YOLUNA YÖNELTME /ss.26-27. İzmir: DOKUZ EYLÜL ÜNIVERSITESİ.

Öztekin, H. (2016). Mutlu İnsanların Küçük Sırları/s.38. İzmir: Nokta e-kitap.

Sağlamtürk, B. R. (2014). The Conquest of Happiness -Mutlu Olma Sanatı/ss.118,182. Ankara: Say Yayınları.

ŞAHİN, D. D.-D. (2011). KUR'AN-I KE RİM VE ME ÂL/ Ra'd13/Lokmân31/Hadîd57/Tevbe9. Ankara: DIYYANET İŞLERİ BAŞKANLIĞI YAYINLARI.

Şems, D. M. (2011). Holy Quran with Turkish Translation Kur'an-i-Kerim ve Turkce Meali. United Kingdom: Islam International Publications.

Sigmund Freud/Çev, J. S. (1989). Civilization and Its Discontents/ s.25. New York: W.W.Norton.

Toktaş, İ.-i. S. (2011). Mutluluk ve İnsan Nefsinin Cevher Olduğuna İlişskin On Delil/s.2629. Ankara: Türkiye Diyanet Vakfı Yayınları.

Yakub bin İshak el-Kindi, e. M. (2014). “Üzüntüyü Yenmenin Çareleri”. İçinde Kindî Felsefî Risâleler/96-395. İstanbul: Klasik Yayınları.

Yıldız, H. (1997). Kur'an da Mutluluk/ s.1-4. Ankara: Ankara Üniversitesi Sosyal Bilimler Enstitüsü/ Basılmamış Yüksek Lisans Tezi. 